\title{
Haeckel and du Bois-Reymond: rival German Darwinists
}

\author{
Gabriel Finkelstein ${ }^{1}$
}

Received: 12 October 2018 / Accepted: 14 January 2019

(c) Springer-Verlag GmbH Germany, part of Springer Nature 2019

\begin{abstract}
Ernst Haeckel and Emil du Bois-Reymond were the most prominent champions of Darwin in Germany. This essay compares their contributions to popularizing the theory of evolution, drawing special attention to the neglected figure of du BoisReymond as a spokesman for a world devoid of natural purpose. It suggests that the historiography of the German reception of Darwin's theory needs to be reassessed in the light of du Bois-Reymond's Lucretian outlook.
\end{abstract}

Keywords Ernst Haeckel $\cdot$ Emil du Bois-Reymond · Darwin · Reception · Germany

\section{Introduction}

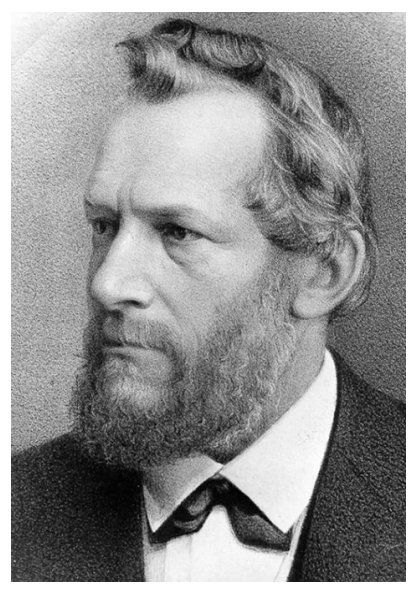

On January 25, 1883, the Professor of Physiology at the University of Berlin, Emil du Bois-Reymond, read a short obituary appended to a speech delivered in celebration of the silver wedding anniversary of the Prussian crown prince and princess. Addressing members of the Academy of Science,

This article is a contribution to the Special Issue Ernst Haeckel (1834-1919): The German Darwin and his impact on modern biology—Guest Editors: U. Hossfeld, G. S. Levit, U. Kutschera.

Gabriel Finkelstein

gabriel.finkelstein@ucdenver.edu

1 Department of History, University of Colorado Denver, PO Box 173364, Denver, CO 80217-3364, USA the Ministry of Education, and the Royal Family, du BoisReymond summed up the significance of his English counterpart: "Darwin seems to me to be the Copernicus of the organic world." Just as the astronomer's theory had displaced the earth from its position at the center of the cosmos, he argued, the biologist's theory had displaced man from his position at the center of nature. Both upheavals had marked revolutions in science (du Bois-Reymond 1883; Finkelstein 2013: 233-264).

As might have been expected, du Bois-Reymond's speech did not sit well with the conservative press. The Kreuzzeitung denounced it as treasonous (Anon 1883f). The Reichsbote noted that it equated man to an ape (-b-1883). Germania attacked it for promulgating a "bestial doctrine" (Zacharias 1883). And the Kölnische Volkszeitung would have recommended prison, but noted that "professors like Mr. Dubois-Reymond, who refer to women in their lectures as human mother-animals (menschliche Muttertiere) should not be crowned with martyrdom" (Anon 1833a). Similar invective poured in from readers. Pastors reproached du Bois-Reymond for materialism (Nathusius 1883). Catholics deemed him worse than nihilists (Anon 1883c, d). Antisemites threatened him with the law of the jungle (Anon 1883e). Critics sent him his photograph with "Look at this ape!" scribbled on the back. "Brother monkeys" invited him to

\footnotetext{
$\overline{1}$ Nachlaß du Bois-Reymond, K. 7 M. 1 Bl. 18-19, Staatsbibliothek zu Berlin, Preußischer Kulturbesitz, Haus Potsdamer Straße, Handschriftenabteilung.
} 
the zoo. ${ }^{2}$ Wags had him proclaiming his fraternity with wildlife (Anon 1883a, b). Most condescendingly, an aristocrat implored him to drop the term "menschliche Muttertiere," since abusing women had never been the "German way.",

The furor then spread to the Prussian parliament, where it provoked 2 days of angry debate. August Reichensperger, the Catholic Center Party deputy for Cologne, regarded du Bois-Reymond's beliefs as little better than those of the "redskins in the wilds of America." Ludwig Windthorst, the leader of the Center Party, was amazed that the rector had been permitted to lecture on Darwin without "express reprobation" and went on to dismiss the theory of evolution as "incomplete and unproven." Not only had du BoisReymond's denied the Mosaic theory of creation, which undergirded the teachings of the Church, but he had also violated the Prussian constitution, which was founded on Christian doctrine. Most outraged was Adolf Stöcker, the leader of the antisemitic Christian Socialist party. Stöcker was appalled that du Bois-Reymond had used a public ceremony to promulgate "crass materialism"; professors were supposed to edify students, not shock them with terms like "human mother-animal." As far as he was concerned, "men with revolutionary tendencies" should not be "appointed to universities and showered with honors." In the past, freethinkers had kept quiet; now "with a salto mortale these self-indulgent celebrities flout the teachings and experience of millennia," threatening to turn German culture "into a sea tossed by storms, today high, tomorrow low, until mankind ultimately founders on the cliffs of folly." More than a little hypocritically, Stöcker exhorted his followers to stone the windows of du Bois-Reymond's institute (Metze 1918: 40-41; Finkelstein 2013: 255-256).

This vignette is telling. Germany has long been recognized as the nation most amenable to Darwin's theory, in part due to talented writers like the Ernst Haeckel, whose popularizations sold hundreds of thousand of copies, and in part due to a large audience of educated workers eager to adopt any doctrine that naturalized progress. What is less well known of this spread of ideas is the role played by du Bois-Reymond. The Prussian neuroscientist has long been reckoned too mechanistic in perspective, too experimental in practice, and too conservative in politics to have had any interest in evolution. In fact, he was the first German professor to adopt Darwin's theory, as well as the first professor to teach it to students at a university. In homage to Theodosius

\footnotetext{
${ }^{2}$ Anonymous postcard, Wiesbaden-Coblenz, 5 February [1883], Nachlaß du Bois-Reymond, K. 7 M. 1 Bl. 7, Staatsbibliothek zu Berlin, Preußischer Kulturbesitz, Haus Potsdamer Straße, Handschriftenabteilung.

${ }^{3}$ L. von Schmeling to Emil du Bois-Reymond, Hamburg, 24 February [1883], Nachlaß du Bois-Reymond, K. 7 M. 1 B1. 29-32, Staatsbibliothek zu Berlin, Preußischer Kulturbesitz, Haus Potsdamer Straße, Handschriftenabteilung; Finkelstein (2013: 255).
}

Dobzhansky, we might even go so far as to say that nothing in German Darwinism makes sense except in the light of du Bois-Reymond.

\section{Rival Darwinians}

Emil du Bois-Reymond (1818-1896) was an unlikely convert. Born the same year as Karl Marx, Emil Brontë, Ivan Turgenev, and Frederick Douglass, he belonged to a generation marked by disappointment: His political hopes failed with the Revolution of 1848 , and his professional hopes were only realized a decade later. By the time he was appointed professor in 1858 most of the steam had bled out his research, and in compensation, he directed his energies to lecturing and writing. The appearance of Darwin's theory encouraged a change in his attitude. Du Bois-Reymond had heard of the Origin of Species from his friend Henry Bence Jones, and though he was unable to obtain a first edition in November 1859 , he picked up a copy of the second printing the following spring. "Darwin's book has not told among our scientific men," he informed Bence Jones on 4 April 1860. "They consider it a slight aberration of intellect, a heterodoxy painful to look at in an otherwise deserving man." ${ }^{4}$ By contrast, du Bois-Reymond found its argument entirely convincing (Darwin 1860; Junker 1991; Junker and Hoßfeld 2001: 64-68; Gliboff 2008). In July he sent Darwin his "Memorial to Johannes Müller"; in November he voiced his "strong approbation" for Darwin's theory to the historian Georg Heinrich Pertz, a man he knew to be married to Charles Lyell's sister; the next summer he helped Darwin obtain an honorary degree from University of Breslau; and he may well have introduced the Origin to Vicky, the Prussian crown princess: Lyell found her "very much au fait" with the book and other novelties in science, like the prehistoric pile-dwellings that du Bois-Reymond had seen in Neuchâtel. ${ }^{5}$

Within a year du Bois-Reymond had drawn up a general survey course highlighting two recent ideas: the conservation of energy and Darwin's theory. These "Findings of Contemporary Science" served as his response to Alexander von Humboldt's Cosmos, a four-volume "sketch of the physical description of the universe" that was the best-selling work

\footnotetext{
${ }^{4}$ Emil du Bois-Reymond to Henry Bence Jones, 4 [April; incorrectly dated March] 1860, Sammlung Darmstaedter 3 k 1852 (3) Bl. 64-68, Staatsbibliothek zu Berlin, Preußischer Kulturbesitz, Haus Potsdamer Straße, Handschriftenabteilung.

${ }^{5}$ Charles Lyell to Charles Darwin, Magdeburg, 16 January 1865 , Letter 4746, Darwin Correspondence Project; Emil du Bois-Reymond to Jeannette Claude, Neuchâtel, Hotel Bellevue, 23 August 1863 (\#128), 3 September 1863 (\#134), Dep. 5 K. 11 Nr. 5, Nachlaß Runge-du Bois-Reymond, Staatsbibliothek zu Berlin, Preußischer Kulturbesitz, Haus Potsdamer Straße, Handschriftenabteilung.
} 
of the day (Rupke 1997, 1:vi). Up to then du Bois-Reymond had typically lectured on physiology, but Humboldt's example led him to the conclusion that popularizers of science "persist in the public mind as memorial stones of human progress long after the waves of oblivion have surged over the originators of the soundest research" (du Bois-Reymond 1912a: 354). ${ }^{6}$ His assessment was correct: Over the three decades that he taught his survey something close to 25,000 students heard him explain Darwin's theory. If you add in the lectures that he delivered to audiences in the Rhineland and the Ruhr, the speeches that he held on official occasions, and the reprints of his public addresses, du Bois-Reymond's impact as a Darwinian was considerable.

The zoologist Ernst Haeckel (1834-1919) offers an interesting comparison. Like du Bois-Reymond, he studied under Johannes Müller; like du Bois-Reymond, he was immediately struck by Darwin's theory; and like du BoisReymond, he offered a course on evolution once he was named professor at the University of Jena (Hoßfeld 2010: 16-17). However, he mistakenly assumed that no one in Berlin had grasped the importance of the Origin, and when he was invited to present Darwin's theory to the Congress of German Scientists and Physicians in 1863, he used the occasion to argue less for the principle of natural selection than for "the threefold parallel between embryological, systematic, and paleontological development." This "biogenetic law," as Haeckel termed his morphological analogy, not only provided "the strongest proof of the truth of evolutionary theory" but also offered science a tool for "reconstructing the history of the lineage" from the sequence of changes apparent in the embryo (Bölsche 1906: 131; Di Gregorio 2005: 86-98; Richards 2008: 100).

Haeckel's emphasis on typological order reappeared in two subsequent books, The General Morphology of Organisms (Haeckel 1866), his most important scientific treatise, and The Natural History of Creation (Haeckel 1868), his first popular publication. In contrast to Darwin's reticence in specifying genealogies of species, Haeckel made so bold as to print stem-trees in both works, vertebrates in the General Morphology and races of men in The Natural History of Creation (Di Gregorio 2005: 195; Richards 2008: 226).

Du Bois-Reymond regarded Haeckel as having pushed things too far. In an address to the Prussian Academy of Sciences in 1876, he argued that morphological laws were more akin to legal maxims than mathematical derivationsevidence from embryology was disparate and evidence from paleontology was inconclusive (du Bois-Reymond 1912b:

\footnotetext{
${ }^{6}$ Henry Bence Jones to Emil du Bois-Reymond, [London], 9 February 1852, Sammlung Darmstaedter 3 k 1852 (3) Bl. 111-112, Staatsbibliothek zu Berlin, Preußischer Kulturbesitz, Haus Potsdamer Straße, Handschriftenabteilung.
}

548-550). The clues to the order of species suggested by Darwin's theory did not support conjectures about the heritage of man. As du Bois-Reymond quipped, Haeckel's family trees of human origins were worth about as much to naturalists "as the pedigrees of Homeric heroes to historians. If I want to read a work of fiction," he added, "I can find something better than a 'History of Creation'" (du Bois-Reymond 1912b: 550; Finkelstein 2013: 250-251).

Du Bois-Reymond saw nothing remarkable in Haeckel's focus on common ancestry. Earlier naturalists, like Goethe, Lamarck, and Geoffroy de Saint-Hilaire, had long been aware of similarities in organic structure. "Anyone with even a moderate familiarity with paleontology," he recounted on another occasion in 1882, "will immediately be led to the idea that life has evolved sequentially to greater perfection. Were he to deny this, he would have to conclude that life either arose out of nothing or appeared in its current stage of development" (du Bois-Reymond 1912d: 176, j: 503-504; Rupke 2005: 143-172). Neither of these alternatives was a serious possibility. "Whoever remains a strict actualist, whoever believes that a molecule of carbon or iron is today what it was eons ago, whoever wishes to imagine the natural world as intelligible," he told his students, "will declare the latter claim to be absurd. There have been as few heroic ages of the earth as there have been of humanity." 7

To his eyes, the real novelty in Darwin's theory lay in the principle of natural selection. This regular process entailed the variation of species, the inheritance of characters, the multiplication of offspring, the competition for resources, and the survival of the fittest-in other words, a mechanism of biological adaptation that avoided the extremes of random accident and divine purpose. By providing this third alternative, that "of establishing blind necessity in the place of final causes," du Bois-Reymond judged Darwin's theory to have constituted "one of the greatest advances ever made in the world of thought" (du Bois-Reymond 1912b: 545). More than one contemporary agreed. The philosopher Otto Caspari likened the struggle between chance and teleology to "a black ghost" haunting "all philosophical consideration of empirical research" (Caspari 1876: 521-522; Ajouri 2014: 22). Similarly, the intellectual historian Friedrich Albert Lange wrote that

Most of those who, in spite of modern science, feel themselves justified in holding fast to teleology, cling to the gaps in scientific knowledge, overlooking the fact that at all events the form of teleology which has existed until now, that is, the anthropo-

\footnotetext{
7 Emil du Bois-Reymond,"Findings of Contemporary Science" (1864), Nachlaß du Bois-Reymond, K. 12 M. 8 Nr. 11 Bl. 25r $-26^{\mathrm{r}}$, Staatsbibliothek zu Berlin, Preußischer Kulturbesitz, Haus Potsdamer Straße, Handschriftenabteilung.
} 
morphic, is utterly disposed of by the facts.... It can now, however, be no longer doubted that nature proceeds in a way which has no similarity with human purposefulness; nay, that her most essential means is such that, measured by the standard of human understanding, it can only be compared with the blindest chance. On this point we need wait for no future proof; the facts speak so plainly and in the most various provinces of nature so unanimously, that no view of things is henceforth admissible which contradicts these facts and their necessary meaning (Lange 1925: 33; Finkelstein 2013: 226-230).

Another historian, Henry Thomas Buckle, expressed the much same sentiment, rejecting final causes as "an old and natural superstition, by which... the German philosophers were long impeded, and which still hangs, though somewhat loosely, about the minds of men" (Buckle 1873, 2: 90-91). And du Bois-Reymond had long believed that even basic concepts of force and matter were nothing other than a "more recondite product of the irresistible tendency to personification" (du BoisReymond 1848-1884, 1: xl-xli). Such animism was antithetical to science. "Final causes in nature are incompatible with its intelligibility," he explained in 1876. "Hence, if there is any way of banishing teleology from nature, the scientist has to take it. A way is found in the theory of natural selection.... In holding fast to this theory, we may feel like a man clinging to a plank that only barely keeps him afloat. When the choice lies between a plank and going under, the advantage is decidedly on the side of the plank" (du Bois-Reymond 1912b: 557). Du BoisReymond's allusion to Lucretius was clear: the Origin of Species may have been a shipwreck, but it was better than going under (Blumenberg 1997).

To be sure, these were not the only differences in outlook between the two German Darwinians. Haeckel traced variation to environmental influences, whereas du BoisReymond remained agnostic about its source (Gliboff 2008: 174). Haeckel accepted the inheritance of acquired characters, whereas du Bois-Reymond rejected it as "perfectly incomprehensible" (Haeckel 1866, 2: 178-179; du Bois-Reymond 1912h: 127-131; du Bois-Reymond 1912k: 129-130). Haeckel advocated a kind of pantheism in which cells passed on inherited memories, whereas du Bois-Reymond thought this idea preposterous (Haeckel 1876: 38-39; Brain 2015: 37-63). Haeckel regarded biology as historical, whereas du Bois-Reymond reduced it to mathematics. And most importantly, Haeckel correlated progress to the division of labor in nature, whereas du Bois-Reymond doubted that evolution equated to advance (Gliboff 2008: 185-186; Finkelstein 2013: 249; Finkelstein 2016).

\section{Rival Prophets}

Why, then, did relations between du Bois-Reymond and Haeckel turn so acrimonious? Both biologists rejected vital forces as agents of adaptation, both judged Christianity to be a retrograde institution, and both deemed anthropomorphism to be the cardinal error of science. Moreover, Haeckel initially approved of du Bois-Reymond, praising the "exceptional industry and brilliant gifts of exposition" displayed in his memorial to Johannes Müller (Haeckel 1931: 77). It was not until 1872, when du Bois-Reymond delivered the keynote address to the Congress of German Scientists and Physicians on "The Limits of Natural Knowledge," that Haeckel broke with his colleague. Responding to du Bois-Reymond's assertion that consciousness was beyond the ken of science, Haeckel accused him of denying the theory of evolution (du Bois-Reymond 1912g, 1: 441-473; Haeckel 1874: xii; Finkelstein 2013: 271). To his mind, du Bois-Reymond's failure to acknowledge the historical development of consciousness placed him in league with the "evil horde" of the Catholic Church (Haeckel 1874: 131). "This seemingly humble but actually presumptuous Ignorabimus," he remarked on the Latin conclusion to du Bois-Reymond's lecture, "is the Ignoratis of the infallible Vatican and of the 'Black International' which it heads" (Haeckel 1874: xiii). Such duplicity was typical of a scholar who knew "all too well how to conceal the weakness of his argument and evidence, and the shallowness of his thought, by striking images and flowery metaphors, and by all the phraseology of rhetoric in which the eloquent French spirit is so superior to our awkward German one" (Haeckel 1878a: 78-79). Du Bois-Reymond's ignorance of natural history had nonetheless blinded him to the fact that consciousness was an "aggregate function of the ganglia" (Haeckel 1876: 24n22; Haeckel 1878a: 86-87). As a result, his lecture was worthless (Haeckel 1868, 1: 237). That mattered little, Haeckel announced; the best counter to the "miserable Ignorabimus" was the prospect of the mind's continuing evolution-no one could foretell what powers it might acquire and what problems it might solve (Haeckel 1877: 19).

Du Bois-Reymond did not wait long to respond. Three years later, in an address on "The Seven Riddles of the Universe," he characterized Haeckel as a "fanatic" who should have known better than to have denounced him as "belonging to the Black Band" of Jesuit priests. Such a comparison "demonstrated once again how near radicalism" (du Bois-Reymond's shorthand for the recent expulsion of the Society of Jesus) "is to despotism" (du BoisReymond 1912c: 67). Haeckel was equally mistaken in criticizing him for ignoring the evolution of the human 
mind. This may have been the case, du Bois-Reymond allowed, but then Haeckel had failed to realize that our species had not altered since the time of Homer, that the world would freeze long before the advent of any superbeings, and that, however, much our brains might develop they could never hope to fathom the intrinsic subjectivity of consciousness. "If anyone has sinned against evolution," du Bois-Reymond pronounced, "it is the Prophet of Jena" (du Bois-Reymond 1912c: 79; Finkelstein 2013: 274).

Haeckel retaliated by protesting du Bois-Reymond's intolerance of disagreement, indicting his ignorance of morphology, disparaging his expressions of doubt, and decrying his position as "the all-powerful secretary and dictator of the Berlin Academy of Sciences" (Haeckel 1876: 23n17; 1878a: 86-87, 1881: 163, 1900: 181; Finkelstein 2013: 279). Haeckel continued to attack his rival for the remainder of his career, an unfortunate tendency that was not helped by du Bois-Reymond's ripostes, such as the accusation that Haeckel played to the crowd, or that he believed that he had solved the riddle of creation, or that his theory of unconscious memories signaled a return of the "hereditary German proclivity to unbridled speculation," or that he ministered to the "idols of confusion" and needed to be thrown out of the temple of science (du Bois-Reymond 1912d: 178, e: 538, i: 143, 151, k: 129). It speaks volumes for the relationship between the two Darwinists that less than 3 years after du Bois-Reymond died Haeckel published his most popular work, The Riddles of the Universe, a clear reference to du Bois-Reymond's address (Haeckel 1900: 16; Paulsen 1900: 72; Finkelstein 2013: 281).

Some of their quarrel can be attributed to genuine disagreement over what constituted proper scientific research. Haeckel trained as marine zoologist, and whether we consider his program of evolutionary morphology a divergence from, an adjunct to, or a fulfillment of Darwinian theory, it is clear that du Bois-Reymond had taken little interest in embryology since he abandoned investigations of the topic in 1840 (Finkelstein 2013: 50-52; divergence from: Montgomery 1974; Bowler 2003; Di Gregorio 2005; adjunct to: Nyhart 2009; Hoßfeld 2010; Gliboff 2008; fulfillment of: Richards 2008). Similarly, Haeckel had little patience for the experiments that had made du Bois-Reymond's name in neurophysiology, just as he had little patience for the philosophers that du Bois-Reymond quoted in his discussion of Darwin (Engelhardt 1980: 287). Even though both their views of evolution were Lucretian, Haeckel did not discover the Roman poet until 1882, whereas du Bois-Reymond first read him in 1838 (Hellems 1906; Nisbet 1986).

More broadly, Haeckel espoused what Mario Di Gregorio has called a "quintessentially conservative" view of knowledge: that of a "system of the universe," a "scientific fundamentalism" eager to displace Christian theology (Di Gregorio 2005: 562, 550). Haeckel imagined nature as a kind of ancien régime, complete with family trees, tables of ranks, and signs of nobility. In consequence, he stood behind the vanguard of his more modern colleagues. When he was not taken as seriously he grew defensive, as he did with the strictures of Wilhelm His and Rudolf Virchow (Bayertz 1983; Kolkenbrock-Netz 1991; Zigman 2000; Richards 2008: 277-341; Hopwood 2015). Du Bois-Reymond shared none of Haeckel's insecurity. Contemporaries recognized him as "the foremost naturalist of Europe," "the last of the encyclopedists," and "one of the greatest scientists Germany ever produced" (Finkelstein 2013: xv). Such confidence helped him to acknowledge brilliance in others, whether in science (as in his admiration of Hermann Helmholtz), or in literature (as in his love of Edgar Allan Poe), or in art (as in his praise of Julia Margaret Cameron).

Du Bois-Reymond understood that natural selection destroyed both purpose and progress: the best that could be said of any species was that it had reached a state of "adaptive equilibrium" (du Bois-Reymond 1912f: 378). Faced with the ultimate mystery of creation, he had learned to be modest. "Research has on the scientific mind an edifying influence like that of life on character," he wrote in 1876.

Being corrected at every step by nature, and constantly reminded of the uncertainty of his judgments and the fallaciousness of his firmest conclusions; being sooner or later infallibly punished for every rash opinion, for every act of blind trust in appearances; being richly rewarded for diligence and fidelity at times other than those he might have hoped: such is the discipline which accustoms the experimental scientist to be chary about brilliant conquests; to approach the truth by gradual steps; to test it as impartially as though his aim were to prove the contrary; and finally, when he has arrived at a number of mutually contradictory facts held together by a tissue of obscure relations, the whole pointing toward various possibilities among which only experience can choose, to keep present to his mind the best of these that he knows (du BoisReymond 1912b: 561).

Du Bois-Reymond suggested that "the small warfare of the laboratory" acted on thought the way that natural selection acted on species. The best ideas might win out, but their truth was always provisional (Finkelstein 2013: 252-253). This was a far cry from Haeckel's claim that he had solved the riddles of the universe. ${ }^{8}$

Which brings me back to du Bois-Reymond's memorial to Darwin. Haeckel accused his rival of plagiarizing his comparison of Darwin to Copernicus, citing a talk he had

\footnotetext{
${ }^{8}$ Except for the one of free will, which he did not regard as "an object for critical, scientific inquiry" (Haeckel 1900: 16).
} 
given to a private circle of friends in 1865 (Haeckel 1883b, 1894: 97n6). Two years earlier Haeckel had compared Darwin to Newton; however, the parallel had also appeared in an obituary of Darwin that du Bois-Reymond read in The Times (Haeckel 1883a: 25-26; Anon 1882). More likely they both picked up the idea from either Thomas Henry Huxley, who had equated Darwin to Copernicus in an article on the Origin for the Westminster Review, or Oskar Schmidt, who had suggested the pairing in a lecture in Vienna. ${ }^{9}$ But that is where the similarity ended. Haeckel portrayed Darwin as a fulfillment of the promise of Lamarck-a messiah, so to speak, who grounded the religion of descent in the theory of selection. Du Bois-Reymond recounted a more profane history. Darwin's contrast with Copernicus reflected less on the men than on their times-we now accept what we once cast away. "While the Holy Inquisition persecuted the followers of Copernicus with fire and sword," du Bois-Reymond wrote in conclusion to his obituary, "Charles Darwin lies buried in Westminster Abbey among his peers, Newton and Faraday" (du Bois-Reymond 1883: 558). Science had vanquished superstition.

It is easy to see why du Bois-Reymond's presentation enraged the Catholic press. The Roman Church in Germany was far from surrendering its claims to authority, especially after surviving the Kulturkampf of anti-clerical legislation of the 1870s. Du Bois-Reymond's intimation that Catholic efforts had been in vain must have struck its followers as particularly insensitive given that recent elections had returned the greatest gains to Left Liberals keen on renewing the fight (Mommsen 1993: 578). Catholics had come to expect broadsides against their faith from popular writers. They did not expect the broadsides to come from someone of the stature of du Bois-Reymond.

But there is an even deeper reason for the reaction of the faithful. In 1883, Germany possessed a large socialist party that believed in the inevitable triumph of a classless society. Du Bois-Reymond's reading of Darwin supported this outlook, describing a world with no fixed order and no natural ranks, only the remorseless prospect of continued strife. To Catholics and conservatives, this was tantamount to anarchy. "Truly, our society cannot persist on the basis of this materialism," wrote the Coblenzer Volkszeitung in response to du Bois-Reymond's obituary. "To what depths of barbarism and bestiality has science sunk? A man who

\footnotetext{
${ }^{9}$ Huxley compared Darwin to Copernicus, Newton, and Kepler in Huxley (1894c: 78) and to Newton and Kepler in Huxley (1894b: 450). He compared Darwin to Newton in Huxley (1894a: 120) and to Copernicus in Huxley (1894d: 252). Finally, he compared Darwin to Newton and Faraday in Huxley (1887) and Schmidt (1866: 19), cited in Michler (1999: 102) and Finkelstein (2013: 262-263). If any plagiarism occurred, it was Haeckel's of du Bois-Reymond. Compare Haeckel (1878b: 181) with du Bois-Reymond (1848-1884, 1: xl-xli).
}

propounds such radical theories is more dangerous than the worst socialist and revolutionary" (Anon 1883d). In the same vein, the Frankfurter Volkszeitung wondered whether Darwin's theory would not throw the world into utter disarray and whether professors who promulgated it were not worse than a "hundred socialists, nihilists, and communists." Du Bois-Reymond's obituary, the newspaper argued, was little better than a "warrant for the Red International" to arm itself with "bombs, petards, and gasoline" (Anon 1883c). Darwin was not just opposed to the Church-Darwin was opposed to civilization.

\section{Conclusion}

Ernst Haeckel remains the best-known spokesman for Darwin in Germany. His Natural History of Creation went through 12 editions, and The Riddles of the Universe sold more than 650,000 copies, making it the most successful work of popular science in German history (Richards 2008: 2-3; Hogrebe 2004: 216). As a result, Haeckel's interpretation of Darwin has generally been taken as paradigmatic (Cassirer 1950: 170-172; Levit and Hoßfeld 2017). On this view, Germans regarded evolution as a theory of development, with natural selection, environmental influence, and genetic inheritance all producing increasing complexity in organic forms. Haeckel's Darwin is progressive.

Emil du Bois-Reymond complicates this story. As a physiologist, he considered natural history to be beside the point - what mattered was natural selection. He arrived at this understanding early in his youth, when a close friend recommended that he read Lucretius..$^{10}$ De Rerum Natura contained the main elements of his popular course of university lectures: a cosmos of matter in motion, an expression of the conservation of energy, a view of life constrained by evolution, and an expectation that the universe would end. It was hardly surprising, then, that the Roman poet prepared him for the Origin of Species - anyone versed in the classics might have felt the same. As Matthew Arnold observed in 1871: "I cannot understand why you scientific people make such a fuss about Darwin. Why, it's all in Lucretius!" (Finkelstein 2013: 248; Judd 1911: 3; Elam 1878: 689-690; Zirkle 1941; Hertling 1880, 1: 73).

Julian Huxley called the six decades between Darwin's death and the modern evolutionary synthesis the "eclipse of Darwinism." Notwithstanding Mark Largent's objections (2009), Huxley's phrase indicates a turn in biology away

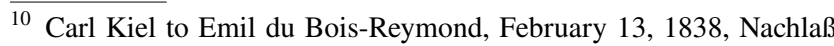
du Bois-Reymond, K. 1M. 6 Bl. 112, Staatsbibliothek zu Berlin, Preußischer Kulturbesitz, Haus Potsdamer Straße, Handschriftenabteilung.
} 
from seeing natural selection as the main agent of evolutionary change. In this regard, the modern synthesis of the 1930s and 1940s may not have constituted a Reformation of the field of natural history, but it did mark a Renaissance in the reputation of Darwin. And yet, I cannot help but wonder at the permanent decline in fortune of Darwin's German champions. Du Bois-Reymond trained thousands of students. Haeckel corresponded with thousands of readers (Hoßfeld 2010: 212). Did they really have no effect on later generations? Did twentieth-century biologists really rediscover du Bois-Reymond's characterization of natural selection as a mechanical, aimless process? And do twenty-first-century studies of genetics and embryology really owe nothing to Haeckel (Hoßfeld and Olsson 2003)? Perhaps the links are missing. I suspect we simply have not found them.

\section{References}

Ajouri P (2014) Darwinism in German-speaking literature (1859-c. 1890). In: Glick T, Shaffer E (eds) The literary and cultural reception of Charles Darwin in Europe. 4 vols, vol 3. Bloomsbury, London, pp 17-45

Anon (1882) Charles Robert Darwin. The Times, 21 April, Nachlaß du Bois-Reymond, K. 5M. 2 Nr. 13. Staatsbibliothek zu Berlin, Preußischer Kulturbesitz, Haus Potsdamer Straße, Handschriftenabteilung

Anon (1833a) Deutsches Reich. Kölnische Volkszeitung 24(29):1

Anon (1883b) In Berlin sind "gelehrte Ochsen"zu sehen. Tirschenreuther Volksbote 11(44):2

Anon (1883c) Politische Streifzüge. Frankfurter Volkszeitung 4(33):1

Anon (1883d) Schnitzel und Späne. Coblenzer Volkszeitung, 2nd edn 12(27): 1

Anon (1883e) Vereine deutscher Stöckerianer. Deutsche Hochschule. Organ der deutschen Studentenschaft, Prague 2(50):3

Anon (1883f) Von der Akademie der Wissenschaften. Neue Preußische Zeitung (=Kreutzzeitung), Erste Beilage, Nr. 23, Berlin, Sunday, 28 January

-b-. (1883) Der Geburtstag Friedrichs des Großen. Der Reichsbote, Zweite Beilage, Nr. 23, Berlin, Sunday, 28 January

Bayertz K (1983) Darwinismus und Freiheit der Wissenschaft. Politische Aspekte der Darwinismus-Rezeption in Deutschland 1863-1878. Scientia 118:267-281

Blumenberg H (1997) Shipwreck with spectator: paradigm of a metaphor for existence (trans: Rendell S). The MIT Press, Cambridge

Bölsche W (1906) Haeckel (trans: McCabe J) Fisher Unwin, London

Bowler P (2003) Evolution: the history of an idea, 3rd edn. University of California, Berkeley

Brain R (2015) The pulse of modernism: physiological aesthetics in Fin-de-Siècle Europe. University of Washington Press, Seattle

Buckle H (1873) History of civilization in England. 3 vols. Longmans, London

Caspari O (1876) Der Begriff der 'Zielstrebigkeit' unter dem Gesichtspunkte der Darwin'schen Lehre. Das Ausland 49(27):521-525 (28):545-548 (29):567-571

Cassirer E (1950) The problem of knowledge: philosophy, science, and history since Hegel (trans: Woglom W, Hendel C). Yale University Press, New Haven

Darwin C (1860) Über die Entstehung der Arten im Thier- und Pflanzen-Reich durch natürliche Züchtung; oder, Erhaltung der vervollkommneten Rassen im Kampfe um's Daseyn (trans: Bronn HG) Schweizerbart, Stuttgart

Di Gregorio M (2005) From here to eternity: Ernst Haeckel and scientific faith. Vandenhoeck \& Ruprecht, Göttingen

du Bois-Reymond E (1848-1884) Untersuchungen über thierische Electrizität. 2 vols. Reimer, Berlin

du Bois-Reymond E (1883) Darwin and Copernicus. Nature 27(702):557-558

du Bois-Reymond E (1912a) Adelbert von Chamisso als Naturforscher. In: der Leibniz-Sitzung der Akademie der Wissenschaften zu Berlin am 28. Juni 1888 gehaltene Rede. In: Reden. 2 vols. Veit, Leipzig, vol 2, pp 353-389

du Bois-Reymond E (1912b) Darwin versus Galiani. In: der LeibnizSitzung der Akademie der Wissenschaften am 6. Juli 1876 Rede. In Reden. 2 vols. Veit, Leipzig, vol 1, pp 540-566

du Bois-Reymond E (1912c) Die Sieben Welträtsel. In: der LeibnizSitzung der Akademie der Wissenschaften am 8. Juli 1880 gehaltene Rede. In: Reden. 2 vols. Veit, Leipzig, vol 2, pp 65-98

du Bois-Reymond E (1912d) Goethe und kein Ende. In: der Aula der Berliner Universität am 15. Oktober 1882 gehaltene Rektoratsrede. In: Reden. 2 vols Veit, Leipzig, vol 2, pp 157-183

du Bois-Reymond E (1912e) La Mettrie. In: der Friedrichs-Sitzung der Akademie der Wissenschaften am 28. January 1875 gehaltene Rede. In: Reden. 2 vols. Veit, Leipzig, vol 1, pp 509-539

du Bois-Reymond E (1912f) Leibnizische Gedanken in der neueren Naturwissenschaft. In der Leibniz-Sitzung der Akademie der Wissenschaften am 7. Juli 1870 gehaltene Rede. In: Reden. 2 vols. Veit, Leipzig, vol 1, pp 370-392

du Bois-Reymond E (1912g) Über die Grenzen des Naturerkennens. In: der zweiten allgemeinen Sitzung der 45. Versammlung Deutscher Naturforscher und Ärzte am 14. August 1872 gehaltener Vortrag. In: Reden. 2 vols. Veit, Leipzig, vol 1, pp 441-473

du Bois-Reymond E (1912h) Über die Übung. Zur Feier des Stiftungsfestes der militärärztlichen Bildungsanstalten am 2. August 1881 gehaltene Rede. In: Reden. 2 vols. Veit, Leipzig, vol 2, pp 99-140

du Bois-Reymond E (1912i) Über die wissenschaftliche Zustände der Gegenwart. In: der Sitzung der Akademie der Wissenschaften zur Geburtstagsfeier des Kaisers und Königs am 23. März 1882 gehaltene Rede. In: Reden. 2 vols. Veit, Leipzig, vol 2, pp 141-156

du Bois-Reymond E (1912j) Über Neo-Vitalismus: Zur Feier der Leibniz-Sitzung der Wissenschaften am 28. Juni 1894 gehaltene Reden. In Reden. 2 vols. Veit, Leipzig, vol 2, pp 492-515

du Bois-Reymond E (1912 k) Über die Übung. Zur Feier des Stiftungsfestes der militärarztlichen Bildungsanstalten am 2. August 1881 gehaltene Rede. In: Reden. 2 vols. Veit, Leipzig, vol 2, pp 99-140

Engelhardt DV (1980) Polemik und Kontroversen um Haeckel. Medizinhistorisches J 15:284-304

Elam C (1878) Man and science: a reply. Ninet Century Mon Rev 3(14):687-711

Finkelstein G (2016) Response to Richards. In: Gjesdal K (ed) Debates in nineteenth-century European philosophy: essential readings and contemporary responses. Routledge, New York, pp 226-230

Finkelstein G (2013) Emil du Bois-Reymond: neuroscience, self, and society in nineteenth-century Germany. The MIT Press, Cambridge

Gliboff S (2008) H. G. Bronn, Ernst Haeckel, and the origins of German Darwinism. The MIT Press, Cambridge

Haeckel E (1866) Generelle Morphologie der Organismen. 2 vols. Reimer, Berlin

Haeckel E (1868) Natürliche Schöpfungsgeschichte. Reimer, Berlin

Haeckel E (1874) Anthropogenie, oder, Entwickelungsgeschichte des Menschen. Gemeinverständliche wissenschaftlich Vorträge über die Grundzüge der menschlichen Keimes- und StammesGeschichte. Engelmann, Leipzig

Haeckel E (1876) Die Perigenesis der Plastidule, oder die Wellenzeugung der Lebenstheilchen. Ein Versuch zur mechanischen 
Erklärung der elementaren Entwickelungs-Vorgänge. Reimer, Berlin

Haeckel E (1877) Ueber die heutige Entwickelungslehre im Verhältnisse zur Gesammtwissenschaft. In: Amtlicher Bericht der 50. Versammlung Deutscher Naturforscher und Aerzte in München vom 17. bis 22. September 1877. Straub, München, pp 14-22

Haeckel E (1878a) Freie Wissenschaft und freie Lehre. Eine Entgegnung auf Rudolf Virchow's Münchener Rede über "Die Freiheit der Wissenschaft im modernen Staat." Schweizerbart'sche Verlagshandlung, Stuttgart

Haeckel E (1878b) Ueber Zellseelen und Seelenzellen. Vortrag, gehalten in der 'Concordia' zu Wien am 22. März 1878. In: Gesammelte populäre Vorträge aus dem Gebiete der Entwicklungslehre. 2 vols. Strauss, Bonn, vol 1, pp 143-181

Haeckel E (1881) Entgegnung. Deutsche Rundschau, vol 29, p 163

Haeckel E (1883a) On the Darwinian theory. Delivered at the First Public Sitting of the Thirty-Eighth Meeting of German Naturalists and Physicians. Stettin, 19 Sept 1863. In: The pedigree of man and other essays (trans: Aveling E). Freethought Publishing Company, London, pp 3-26

Haeckel E (1883b) The origin of the human race (1865). In: The pedigree of man and other essays (trans: Aveling E). Freethought Publishing Company, London, pp 29-53

Haeckel E (1894) Monism as connecting religion and science: the confession of faith of a man (trans: Gilchrist J). Black, London

Haeckel E (1900) The riddle of the universe at the close of the nineteenth century (trans: McCabe J). Harper Brothers, New York

Haeckel E (1931) Anna Sethe. Die erste Liebe eines berühmten Mannes in Briefen. In: Schmidt H (ed) Reißner, Dresden

Hellems F (1906) Lucretius and Haeckel before the Riddles of the Universe. The University of Colorado Studies 3(3):121-134, 3(4):217-228

Hertling G (1880) Der Darwinismus, eine geistige Epidemie. In: Haffner P (ed) Frankfurter zeitgemäße Broschüren. Foesser, Frankfurt am Main, vol 1, pp 41-77

Hogrebe W (2004) Grenzen und Grenzüberschreitungen: XIX. Deutscher Kongreß für Philosophie, 2002, Bonn. Vorträge und Kolloquien. Akademie-Verlag, Berlin

Hopwood N (2015) Haeckel's embryos. images, evolution, and fraud. The University of Chicago Press, Chicago

Hoßfeld U (ed) (2010) Absolute Ernst Haeckel. Orange-Press, Freiburg

Hoßfeld U, Olsson L (2003) The road from Haeckel: The Jena tradition in evolutionary morphology and the origins of "Evo-Devo". Biol Philos 18:285-307

Huxley TH (1887) On the reception of the "origin of species". In: Darwin F (ed) The life and letters of Charles Darwin, including an autobiographical chapter. 2 vols, vol 1. Appleton, New York, pp 533-558

Huxley TH (1894a) Mr. Darwin's Critics. In: Darwiniana: essays. Macmillan, London, pp 120-186

Huxley TH (1894b) On our knowledge of the causes of the phenomena of organic nature. Six lectures to working men. In: Darwiniana: essays. Macmillan, London, pp 303-475

Huxley TH (1894c) The origin of species. In: Darwiniana: essays. Macmillan, London, pp 22-79

Huxley TH (1894d) Copernicus in "The Darwin Memorial”. In: Darwiniana: essays. Macmillan, London, pp 248-252

Judd J (1911) The coming of evolution: the story of a great revolution. Cambridge University, Cambridge

Junker T (1991) Heinrich Georg Bronn und die Entstehung der Arten. Sudhoffs Archiv 75:180-208

Junker T, Hoßfeld U (2001) Die Entdeckung der Evolution. Eine revolutionäre Theorie und ihre Geschichte. Wissenschaftliche Buchgesellschaft, Darmstadt
Kolkenbrock-Netz J (1991) Wissenschaft als nationaler Mythos. Anmerkungen zur Haeckel-Virchow-Kontroverse auf der 50. Jahresversammlung deutscher Naturforscher und Ärzte in München (1877). Nationale Mythen und Symbole in der zweiten Hälfte des 19. Jahrhunderts. In: Link J, Wülfung W (eds) Strukturen und Funktionen von Konzepten nationaler Identität. Klett-Cotta, Stuttgart, pp 212-236

Lange F (1925) The history of materialism and criticism of its present importance, 3rd edn (trans: Thomas E). Harcourt, Brace, New York

Largent M (2009) The so-called eclipse of Darwinism. Trans Am Philos Soci New Ser 99(1):3-21

Levit GS, Hoßfeld U (2017) Major research traditions in twentiethcentury evolutionary biology: the relations of Germany's Darwinism with them. In: Delisle R (ed) The Darwinian tradition in context: research programs in evolutionary biology. Springer, Cham, pp 169-193

Metze E (1918) Emil du Bois-Reymond. Sein Wirken und seine Weltanschauung, 3rd edn. Breitenbach, Bielefeld

Michler W (1999) Darwinismus und Literatur: Naturwissenschaftliche und literarische Intelligenz in Österreich, 1859-1914. Böhlau, Vienna

Mommsen W (1993) Das Ringen um den nationalen Staat. Die Gründung und der innere Ausbau des Deutschen Reiches unter Otto von Bismarck, 1850 bis 1890. Propyläen, Frankfurt am Main

Montgomery W (1974) Germany. In: Glick T (ed) The comparative reception of Darwinism. University of Texas, Austin

Nathusius MV (1883) Dubois-Reymond und die christliche Weltanschauung. Allgemeine Conservative Monatsschrift für das christliche Deutschland 40:322-328

Nisbet HB (1986) Lucretius in eighteenth-century Germany. With a Commentary on Goethe's "Metamorphose der Tiere". Mod Lang Rev 81(1):97-115

Nyhart L (2009) Embryology and morphology. In: Ruse M, Richards $\mathrm{R}$ (eds) The Cambridge companion to the "origin of species". Cambridge University Press, Cambridge, pp 194-215

Paulsen F (1900) Haeckel als Philosoph. Preußische Jahrbücher, vol 101, pp 29-72

Richards R (2008) The tragic sense of life: Ernst Haeckel and the struggle over evolutionary thought. The University of Chicago Press, Chicago

Rupke N (1997) Introduction to the 1997 Edition. In: Cosmos (trans: Otté EC) 2 vols. Johns Hopkins University Press, Baltimore, vol 1 , pp vi-xlii

Rupke N (2005) Neither creation nor evolution: the third way in midnineteenth century thinking about the origin of species. Ann Hist Philos Biol 10:143-172

Schmidt O (1866) Das Alter der Menschheit. In: Schmidt O, Unger F (eds) Das Alter der Menschheit und das Paradies. Zwei Vorträge. Braumüller, Vienna, pp 1-36

Zacharias O (1883) Die Staatsgefährlichkeit der Naturforschung. Leipziger Tageblatt und Anzeiger 77(45):765-766

Zigman P (2000) Ernst Haeckel und Rudolf Virchow. Der Streit um den Charakter der Wissenschaft in der Auseinandersetzung um den Darwinismus. Medizinhistorisches J 35:263-302

Zirkle C (1941) Natural selection before the origin of species. Proc Am Philos Soc 84(1):71-123

Publisher's Note Springer Nature remains neutral with regard to jurisdictional claims in published maps and institutional affiliations. 